\title{
PENINGKATAN KEMAMPUAN KERJASAMA MELALUI MODEL PROJECT BASED LEARNING (PJBL) BERBANTUAN METODE EDUTAINMENT PADA MATA PELAJARAN ILMU PENGETAHUAN SOSIAL
}

\author{
Ika Ari Pratiwi ${ }^{\bowtie 1}$, Sekar Dwi Ardianti ${ }^{2}$, dan Moh. Kanzunnudin ${ }^{3}$ \\ ${ }^{1,2}$ Prodi Pendidikan Guru Sekolah Dasar FKIP Universitas Muria Kudus \\ ${ }^{3}$ Prodi Pendidikan Bahasa dan Sastra Indonesia FKIP Universitas Muria Kudus
}

\begin{tabular}{|c|c|}
\hline Info Artikel & Abstract \\
\hline $\begin{array}{l}\text { Sejarah Artikel: } \\
\text { Diterima: } 19 \text { Jan } 201 \\
\text { Direvisi : } 5 \text { Feb } 2018 \\
\text { Dipublikasikan: Jun } 2018\end{array}$ & $\begin{array}{l}\text { The purpose of this study is to describe the ability of cooperation and student learning outcomes using } \\
\text { edutainment-based project-based learning model. The research method used control group post-test } \\
\text { design, which consist of control group and experiment group. The result of t-test of cooperative ability } \\
\text { analysis showed that t-count value 3,279>t-table 2,011 and analysis of student learning result with t-test } \\
\text { showed that t-count value 2,854>t-table 2, 011. Then there is significant difference of cooperation } \\
\text { ability and the post test score of the experimental group students with the control group. Thus the model }\end{array}$ \\
\hline $\begin{array}{l}\text { Keywords: } \\
\text { cooperative ability, project }\end{array}$ & $\begin{array}{l}\text { of project based learning }(P j B L) \text { assisted edutainment method can improve the ability of cooperation and } \\
\text { learning outcomes of fourth graders of } S D \text { Muhammadiyah Kudus. }\end{array}$ \\
\hline
\end{tabular}

based learning model, edutainment method

\begin{abstract}
Abstrak
Tujuan penelitian ini untuk mendeskripsikan kemampuan kerjasama dan hasil belajar siswa menggunakan model project based learning berbantuan edutainment. Metode penelitian yang digunakan control group post-test design, yang terdiri dari kelompok kontrol dan kelompok eksperimen. Hasil uji-t analisis kemampuan kerjasama menunjukkan bahwa nilai t-hitung 3,279>t-tabel 2,011 dan analisis hasil belajar siswa dengan uji-t menunjukkan bahwa nilai t-hitung 2,854 > t- tabel 2, 011. Maka terdapat perbedaan yang signifikan kemampuan kerjasama dan nilai post test siswa kelompok ekperimen dengan kelompok kontrol. Dengan demikian model project based learning $(P j B L)$ berbantuan metode edutainment dapat meningkatkan kemampuan kerjasama dan hasil belajar siswa kelas IV SD Muhammadiyah Kudus.
\end{abstract}

(C) 2018 Universitas Muria Kudus

\footnotetext{
${ }^{\square}$ Alamat korespondensi:

Program Studi Pendidikan Guru Sekolah Dasar

Fakultas Keguruan dan Ilmu Pendidikan Universitas Muria Kudus

Kampus UMK Gondangmanis, Bae Kudus Gd. L. It I PO. BOX 53

Kudus

Tlp (0291) 438229 ex.147 Fax. (0291) 437198

E-mail: ika.ari@umk.ac.id
} 


\section{PENDAHULUAN}

Ilmu Pengetahuan Sosial merupakan mata pelajaran di sekolah dasar yang mempelajari tentang konsep-konsep, gejala dan fakta sosial di masyarakat. Samlawi dan Maftuh (2001) menjelaskan Ilmu Pengetahuan Sosial mengintegrasikan konsep-konsep terpilih dari ilmu sosial dan humaniora untuk tujuan pembinaan warga negara yang baik. Katon dkk (2016) mengemukakan ruang lingkup IPS mengkaji tentang kehidupan masa lampau, kenampakan dan fenomena sosial budaya, interaksi manusia dengan lingkungan yang bertujuan untuk pembentukan karakter yang baik. IPS merupakan salah satu mata pelajaran yang mengajarkan siswa bagaimana berinterikasi dalam kegiatan sosial, memahami keberagaman individu dan kelompok, serta kebudayaan di masyarakat.

Siswa sejak dini harus dimotivasi untuk melakukan suatu kegiatan secara bersama atau berkelompok, hal ini untuk menghindari sikap egois pada diri siswa. Pratiwi (2015) mengemukakan bahwa secara emosional masih ada siswa yang tidak mau membantu temannya serta ada beberapa siswa yang malu karena dipandang lemah jika meminta bantuan teman. Guru sebagai fasilitator dan motivator sebaiknya memberikan arahan dan kesempatan kepada siswa untuk bekerjasama membangun kekompakan dan kebersamaan dalam kegiatan pembelajaran di sekolah. Apriono (2011) menjelaskan kemampuan kerjasama dapat diartikan sebagai kemampuan yang dilakukan oleh beberapa siswa untuk saling membantu satu sama lain sehingga tampak kebersamaan dan kekompakan untuk mencapai tujuan bersama.

Aspek kemampuan kerjasama yang digunakan pada kegiatan pembelajaran oleh Eggen dan Kauchak dalam Apriono (2011: 167) yaitu: (1) dengan sopan mendengarkan oranglain berbicara dan baru berbicara setelah oranglain selesai bicara, (2) berinterupsi dengan sopan, (3) menghargai ide orang lain, (4) menangkap ide orang lain dengan tepat sebelum menyatakan tidak setuju, dan (5) mendukung setiap partisipasi anggota kelompok.

Kriteria kemampuan kerjasama berdasar hasil penelitian Maasawet (2011: 21) adalah: 1) memberi informasi sesama anggota kelompok, 2) dapat menyelesaikan perselisihan yang terjadi, 3) menciptakan suasana kerjasama yang akrab, 4) bertukar ide dan pendapat kepada anggota kelompok, 5) mendukung keputusan kelompok, 6) menghargai masukan dan keahlian anggota lain, 7) berpartisipasi melaksanakan tugas, 8) mengahrgai hasil kerja kelompok.

Berdasarkan beberapa teori yang diadaptasi sesuai kebutuhan peneliti, maka aspek kemampuan kerjasama yang akan dikembangkan dalam penelitian ini adalah peningkatan kemampuan kerjasama siswa pada aspek: 1) kebersamaan siswa menyelesaikan tugas proyek, 2) mendiskusikan perencanaan proyek dengan tepat, 3) saling tukar pendapat, dan 4) kekompakan dalam menyelesaikan tugas proyek.

Salah satu hal yang mampu mendukung kemampuan bekerjasama siswa adalah menerapkan model project based learning $(P j B L)$ pada pembelajaran IPS. Pada kegiatan pembelajaran ini siswa menyelesaikan sebuah proyek secara berkelompok untuk menyelesaikan suatu produk. Kelompok terdiri atas karakter siswa yang heterogen, mereka dilatih untuk bisa saling mengisi dan memberi, sehingga terjalin kekompakan dan kebersamaan untuk menyelesaikan proyeknya dengan baik. Siswa bersama timnya melaksanakan proyeknya membuat album sesuai dengan tahapan model project based learning (PjBL) yang telah diinstruksikan oleh guru.

Ardianti dkk (2017: 146) mengemukakan project based learning ( $\mathrm{PjBL}$ ) merupakan salah satu model pembelajaran yang bercirikan adanya kegiatan merancang dan melakukan sebuah proyek untuk menghasilkan sebuah produk. Kosasih (2014: 96) menjelaskan pembelajaran berbasis proyek adalah model pembelajaran dengan menggunakan proyek sebagai tujuannya. Sari dkk (2015: 4) menjelaskan model project based learning (PjBL) merupakan suatu model pembelajaran yang mampu membangun kemampuan siswa dengan melibatkan kerja proyek yang menghasilkan suatu karya nyata yang dapat diperlihatkan seperti laporan, pembuatan produk dan penyelesaian tugas tertulis yang guru berikan.

Tahapan model project based learning (PjBL) pada penelitian ini menggunakan pendapat Wena (2012: 144) yaitu: 1) penentuan pertanyaan mendasar (Start With the Essential Question), 2) mendesaiin perencanaan proyek (Design a Plan for the Project), 3) menyusun jadwal kegiatan (Create a Schedule), 4) memoitor siswa dan kemajuan proyek (Monitor the Students and the Progress of the Project), 5) menguji hasil (Assess the Outcome), dan 6) mengevaluasu pengalaman (Evaluate the Experience). 
Pada penerapan model project based learning (PjBL) pembelajaran IPS didukung oleh bantuan metode edutainment. Metode edutainment dari bahasa Inggris yaitu pendidikan yang menghibur atau menyenangkan (Agustriana 2013: 270). Pada proses pembelajaran edutainment didesain muatan pembelajarannya dikombinasikan dengan hiburan yang menyenangkan melalui permainan. Edutainment sebagai proses pembelajaran yang memadukan antara muatan pendidikan dan hiburan secara harmonis sehingga aktivitas pembelajaran berlangsung menyenangkan.

Berdasarkan penjelasan di atas sebagai upaya untuk meningkatkan kemampuan kerjasama dan menarik minat belajar siswa kelas IV, tidak hanya dengan menghafal namun juga dengan bermain, menempel-menempel dan memberi hiasan album keberagaman kebudayaan di Jawa Tengah dengan menggunakan metode edutainment pada penerapan model project based learning ( $\mathrm{PjBL})$ di SD Muhammadiyah Kudus.

\section{METODE PENELITIAN}

Subjek penelitian ini adalah siswa kelas 4 SD 1 Muhammadiyah Kabupaten Kudus tahun 2016/2017 semester gasal. Penelitian ini dilakukan menggunakan pendekatan kuantitatif dengan teknik pengambilan sampel secara random. Metode yang digunakan pada penelitian ini adalah control group post-test design. Penelitian ini terdiri dari atas kelompok ekperimen dan kelompok kontrol. Kelompok ekperimen di kelas IVA dengan menggunakan model project based learning berbantuan metode edutainment, sedangkan kelompok kontrol di kelas IVB dengan model biasa dengan diskusi kelompok.

Variabel penelitian ini adalah model peroject based learning (PjBL) berbantuan metode edutainment sebagai variabel bebas (X) dan peningkatan hasil belajar sebagai variabel terikat (Y). Teknik pengumpulan data dan instrumen yang digunakan pada penelitian ini meliputi: 1) lembar soal pre test dan post test yang sudah teruji validitas dan reliabilitasnya dan 2) lembar observasi untuk mengamati kemampuan kerjasama siswa pada saat pembelajaran berlangsung.

Analisis data statistik yang dilakukan untuk pengukuran hasil penelitian yaitu: 1) uji normalitas untuk melihat normal dan tidaknya data penelitian menggunggunakan chi kuadrat, 2) analisis pengaruh model terhadap kemampuan kerjasama untuk mengetahui perbedaan rerata dari skor kemampuan kerjasama siswa dan 3) analisis pengaruh model terhadap post test siswa.

\section{HASIL DAN PEMBAHASAN}

Penelitian yang dilaksanakan pada siswa kelas IV SD Muhammadiyah Kudus berupa skor hasil observasi kemampuan kerjasama siswa. Kemapuan kerjasama siswa diamati saat siswa secara berkelompok membuat album keragaman budaya. Hasil rekapitulasi kemampuan kerjasama siswa setiap aspek tampak pada Tabel 1 berikut.

Tabel 1. Rekapitulasi Aspek Kerjasama Siswa Kelas Eksperimen dan Kontrol

\begin{tabular}{ccc}
\hline \multirow{2}{*}{$\begin{array}{c}\text { Rata-rata } \\
\text { (Aspek) }\end{array}$} & \multicolumn{2}{c}{ Skor Kreativitas Siswa } \\
\cline { 2 - 3 } & $\begin{array}{c}\text { Kelompok } \\
\text { Eksperimen }\end{array}$ & $\begin{array}{c}\text { Kelompok } \\
\text { Kontrol }\end{array}$ \\
\hline Kebersamaan & 2,52 & 2,15 \\
Diskusi & 1,77 & 1,69 \\
Bertukar & 2,53 & 1,89 \\
$\begin{array}{c}\text { Pendapat } \\
\text { Kekompakan }\end{array}$ & 1,88 & 1,79 \\
\hline $\begin{array}{c}\text { Total Rata- } \\
\text { rata }\end{array}$ & $\mathbf{8 , 7 0}$ & $\mathbf{7 , 5 2}$ \\
\hline
\end{tabular}

Hasil kemampuan kerjasama siswa ada 4 aspek, hasil rata-rata setiap aspek yaitu: 1) kebersamaan memperoleh rata-rata kelompok eksperimen 2,52 dan kelompok kontrol 2,15; 2) diskusi memperoleh rata-rata kelas eksperimen 1,77 dan kelas kontrol 1,69; 3) bertukar pendapat memperoleh rata-rata kelas eksperimen 2,53 dan kelas kontrol 1,89; 4) kekompakan memperoleh rata-rata kelompok eksperimen 1,88 dan kelompok kontrol 1,79. Hasil rata-rata tersebut berdasarkan pada hasil checklist siswa pada kegiatan pembelajaran. Isi checklist ada 10 item yang merupakan pengembangan dari 4 aspek tersebut, setiap aspek terdiri dari 2 - 3 item soal.

Total skor kemampuan kerjasama siswa pada kelompok eksperimen dan kelompok kontrol secara klasikal disajikan pada Tabel 2 berikut. 
Tabel 2. Rekapitulasi skor kemampuan kerjasama siswa.

\begin{tabular}{ccc}
\hline \multirow{3}{*}{ Komponen } & \multicolumn{2}{c}{$\begin{array}{c}\text { Skor Kemampuan } \\
\text { Kerjasama Siswa }\end{array}$} \\
\cline { 2 - 3 } & $\begin{array}{c}\text { Kelompok } \\
\text { Eksperimen }\end{array}$ & $\begin{array}{c}\text { Kelompok } \\
\text { Kontrol }\end{array}$ \\
\hline Rata-rata & 8,70 & 7,52 \\
$\begin{array}{c}\text { Skor } \\
\text { tertinggi } \\
\text { Skor } \\
\text { terendah }\end{array}$ & 10 & 10 \\
\hline
\end{tabular}

Berdasarkan hasil rekapitulasi pada Tabel 2, maka skor kemampuan kerjasama siswa kelompok eksperimen dan kontrol dapat disajikan pada Gambar 1 berikut.

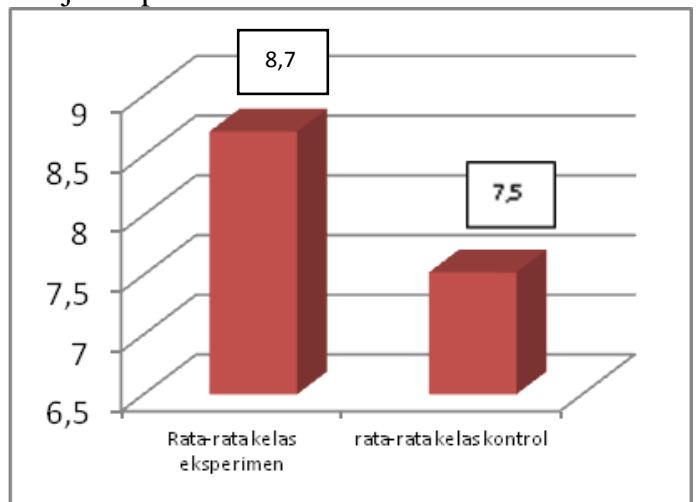

Gambar 1. Rekapitulasi skor kerjasama siswa kelas eksperiment dan kontrol

Hasil perolehan skor kemampuan kerjasama siswa pada kelompok eksperimen lebih tinggi dibandingkan dengan siswa kelompok kontrol. Hal tersebut dapat dilihat pada skor rata-rata kemampuan kerjasama siswa kelompok eksperimen mencapai 8,70 sedangkan kelompok kontrol mencapai 7,52. Skor kemampuan kerjasama siswa tersebut kemudian dianalisis secara statistik menggunakan uji-t. Hasil uji-t menunjukkan hasil bahwa nilai thitung 3,279>t-tabel 2,011. Nilai tersebut menunjukkan bahwa terdapat perbedaan yang signifikan antara skor kemampuan kerjasama siswa kelompok eksperimen dengan kontrol.

Penelitian penerapan model project based learning (PjBL) berbantuan metode edutainment menunjukkan bahwa terdapat peningkatan pada setiap aspek kemampuan kerjasama. Adanya pembuatan proyek pembuatan album antar siswa dalam kelompok melakukan diskusi dan bertukar pendapat mengenai cara mengerjakan tugas yang tepat, serta pemberian hiasan atau variasi pada album tersebut. Tampak adanya kebersamaan siswa dalam kelompok untuk menjadi tim dalam membuat album yang terbaik. siswa dengan kompak membagi tugas dalam pembuatan album ada yang menggunting, menempel, memberi variasi warna dan menggambar album yang dibuat sehingga proyek pembuatan album dapat siswa selesaikan dengan baik. Diakhir kegiatan pembelajaran dengan model project based learning, secara bergantian masingmasing kelompok mempresentasikan hasil produknya sedangkan kelompok lain memperhatikan dan memberikantanggapan.

Kegiatan pembelajaran dengan model PjBL berbantuan metode edutainment menuai manfaat bagi siswa untuk meningkatkan kemampuan bekerjasama dengan teman dalam pembuatan tugas (album keanekaragaman budaya di Jawa Tengah). Hasil penelitian ini sejalan dengan pernyataan Rahmawati (2006: 12) bahwa kerjasama bermanfaat bagi siswa diantaranya: 1) siswa merasa sadar diri sebagai anggota kelompok, 2) siswa merasa sadar diri memiliki tujuan bersama berupa tujuan kelompok, 3) siswa memiliki kemampuan berinteraksi dan berkomunikasi dengan siswa lainnya, 4) siswa memiliki tindakan bersama sebagai perwujudan tanggungjawab kelompok, dan 5) pemenuhan kebutuhan bersosialisasi.

Pembiasaan kegiatan pembelajaran secara berkelompok dapat menghindari dan mengatasi sikap individualis dan egois siswa. Kemamouan bekerjasama pada masing-masing siswa dapat menciptakan sikap toleransi, dimana tindakan menghargai pendapat, sikap dan tindakan oranglain yang berbeda dengan dirinya. Kegiatan kelompok memunculkan tindakan yang memperlihatkan rasa senang bergaul dengan oranglain melalui kegiatan bekerjasama (Puskur 2010: 8-9).

Hasil belajar siswa pada penelitian ini merupakan hasil ranah kognitif yang diperoleh dari post test. Hasil post test siswa pada kelas eksperimen dan kelas kontrol disajikan pada Tabel 3 berikut.

Tabel 3. Rekapitulasi hasil post test siswa kelas eksperiment dan kontrol

\begin{tabular}{ccc}
\hline \multirow{2}{*}{ Komponen } & \multicolumn{2}{c}{ Nilai Post test } \\
\cline { 2 - 3 } & $\begin{array}{c}\text { Kelas } \\
\text { Eksperimen }\end{array}$ & $\begin{array}{c}\text { Kelas } \\
\text { Kontrol }\end{array}$ \\
\hline Rata-rata & 64,8 & 52,9 \\
Skor tertinggi & 86,7 & 78,0 \\
Skor & 29,0 & 19,4 \\
terendah & & \\
\hline
\end{tabular}

Berdasarkan hasil rekapitulasi pada Tabel 4.5, maka nilai hasil post test siswa 
kelompok eksperimen dan kelompok kontrol disajikan pada diagram Gambar 2.

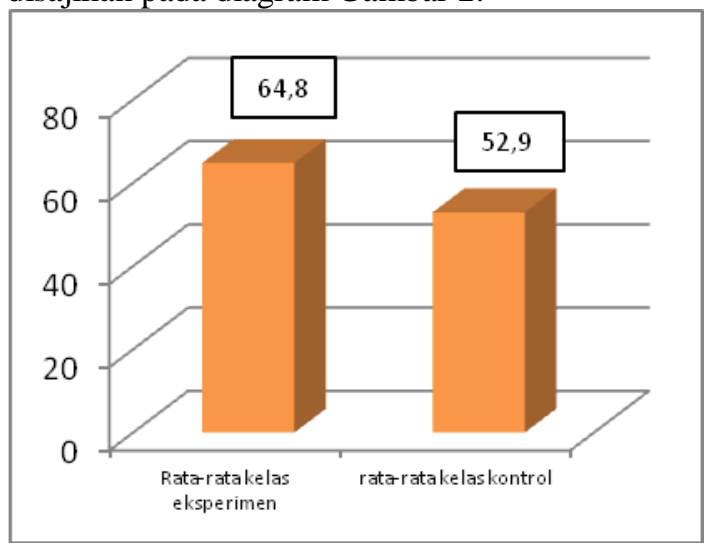

Gambar 2. Rekapitulasi hasil posttest siswa kelas eksperiment dan kontrol

Hasil post test siswa pada kelas eksperimen lebih tinggi dibandingkan dengan siswa kelas kontrol. Hal tersebut dapat dilihat pada skor rata-rata nilai post test siswa kelas eksperimen mencapai 64,8 sedangkan kelas kontrol mencapai 52,9. Nilai post test tersebut selanjutnya dianalisis secara statistik menggunakan uji-t. Hasil analisis uji-t menunjukkan bahwa nilai t-hitung 2,854 > ttabel 2,011. Hal tersebut menunjukkan bahwa ada perbedaan yang signifikan antara nilai post test siswa kelas ekperimen dengan kelas kontrol.

Metode edutainment pada model project based learning (PjBL) adalah siswa membuat "album keragaman budaya Jawa Tengah" yang dikreasikan oleh gambar-gambar keragaman budaya di Jawa Tengah secara berkelompok. Sepakat dengan Dewi dkk (2014) yang menyatakan bahwa diterapkannya metode edutainmet lebih banyak menekankan aktivitas siswa daripada guru, melalui pembelajaran antar kelompok dengan pemberian masalah dan merangkai gambar, keaktifan belajar tersebut membuat siswa mendapatkan pengetahuan dengan cara yang bermakna dan tidak membosankan. Ardianti dkk (2017: 2) mengemukakan proses pembelajaran selain mengajak siswa aktif diharapkan mampu mengajak berinteraksi dengan lingkungan.

Pada kegiatan pembelajaran ini siswa bekerjasama membuat album yang memuat makanan khas, alat tradisional, pakaian daerah, dan upacara adat di Jawa Tengah. Selain kekompakan dan kebersamaan hasil dari kegiatan kerjasama ini dapat menghasilkan suatu produk kelompok yang kreatif dan menarik (edutainment) yaitu album keragaaman budaya di Jawa Tengah. Album ini menarik bagi siswa karena mereka mampu mempelajari materi tidak hanya dengan menghafal namun juga dengan bermain, menempel-menempel dan memberi hiasan pada album yang dibuat. Ketika telah menjadi sebuah album siswa tidak anak merasa bosan belajar karena mereka dapat mempelajari berbagai keragaman budaya di Jawa Tengah dari beberapa gambar dan keterangan gambar yang mereka tulis sesuai kreativitasnya. Pada akhirnya pembelajaran ini akan lebih dikenang dan bermakna bagi siswa, sehingga secara nyata hasil belajar siswa meningkat.

Hasil penelitian ini sejalan dengan hasil penelitian Sucipto (2017:84) bahwa dengan model project based learning siswa dapat berpatisipasi penuh saat pembelajaran, karena model ini dituntut agar dapat mengkonstruk pengetahuan mereka. Setiap anggota kelompok memiliki tanggungjawab masing-masing dalam mengerjakan tugas proyek, sehingga tidak ada yang dianggap menumpang kepada anggota yang lain. Pada penelitian ini siswa dilatih untuk bekerja dengan teman lain. Dominguez (2010) menjelaskan bahwa bekerja dengan oranglain mampu meningkatkan keterlibatan belajar, berbagi ide-ide dan menanggapi reaksi oranglain meningkatkan pemikiran dan pemahaman mendalam. Pada akhirnya dengan menggunakan model project based learning berbantuan metode edutainment dapat meningkatkan kemampuan kerjasama siswa.

\section{SIMPULAN}

Berdasarkan analisis hasil penelitian dengan uji-t dapat disimpulkan bahwa model project based learning berbantuan metode edutaiment dapat meningkatkan kemampuan kerjasama dan hasil belajar siswa. Hasil uji-t menunjukkan bahwa terdapat perbedaan yang signifikan antara kelas kontrol dan kelas eksperimen pada peningkatan kemampuan kerjasama. Hal tersebut juga berdampak positif pada peningkatan hasil belajar IPS siswa kelas IV di SD Muhammadiyah Kudus.

\section{DAFTAR PUSTAKA}

Agustriana, N. 2013. Pengaruh Metode Edutainment dan Konsep Diri Terhadap Ketrampilan Sosial Anak. Jurnal Pendidikan Usia Dini, 7 (2): 267-286.

Apriono, D. 2011. Meningkatkan Keterampilan Kerjasama Siswa Dalam Belajar Melalui Pembelajaran Kolaboratif. Jurnal Prospektus, IX (2). 
Ardianti, S.D., Wanabuliandari, S., dan Rahardjo, S. 2017. Peningkatan Perilaku Peduli Lingkungan dan Tanggungjawab Siswa Melalui Model EJAS dengan Pendekatan Science Edutainment. Jurnal Ilmiah Pendidikan Dasar, IV (1): 1-7.

Ardianti, S.D., Pratiwi, I.A., dan Kanzunnudin, Moh. 2017. Implementasi Project Based Learning (PjBL) Berpendekatan Science Edutainment Terhadap Kreativitas Peserta Didik. Jurnal Refleksi Edukatika, 7 (2): 145-150.

Dewi, T.P., dkk. 2014. Pengaruh Metode Edutainment terhadap Hasil Belajar IPA Siswa kelas S SD di Gugus XV. $e$ Journal Mimbar PGSD Universitas Pendidikan Ganesha, 2 (1).

Dominguez, D. 2010. "Principle 2: Good Practice Encourages Cooperation Among Students. Brigham Young University" .Journal of Legal Education, 49: 386400.

Katon, IC. Riyadi dan Djaelani. 2016. Peningkatan Sikap Kerjasama Melalui Penerapan Numbered Heads Together. Jurnal Didaktika Dwija Indira 4 (2).

Kosasih. 2014. Strategi Belajar dan Pembelajaran Implementasi Kurikulum 2013. Bandung: Yrama Widya.
Maasavet, E. T. 2011. "Meningkatkan Kemampuan Kerjasama Belajar Biologi Melalui Penerapan Strategi Inkuri Terbimbing Pada Siswa Kelas VII SMP Negeri 6 Kota Samarinda. Samarinda". Jurnal Bioedukasi, 2 (1).

Pratiwi, I.A., 2015. Pengembangan Model Kolaborasi Jigsaw Role Playing sebagai Upaya Peningkatan Kemampuan Bekerjasama Siswa Kelas V SD Pada Pelajaran IPS. Jurnal Gusjigang 1 (2).

Puskur. 2010. Pengembangan Pendidikan Budaya dan karakter Bangsa. Jakarta: Kemendiknas.

Samlawi dan Maftuh. 2001. Konsep Dasar IPS. Bandung: CV. Maulana.

Sucipto, H. 2017. Penerapan Model Project Based Learning untuk Meningkatkan Minat dan Hasil Belajar IPS. Jurnal Pendidikan: Riset \& Konseptual, .1 (1): $77-86$

Wena, Made. 2011. Strategi Pembelajaran Inovatif Kontemporer: Suatu Tinjauan Konseptual Operasional. Jakarta: Bumi Aksara 